\title{
Effect of Integrated Marketing Communications on Customer Satisfaction of Selected Private Universities in South-West Nigeria
}

\author{
Adegbola Eunice Abimbola $^{1}$, Binuyo Adekunle Oluwole ${ }^{2} \&$ Afolabi Gabriel Kolawole $^{3}$ \\ 1, 2 \& 3 Department of Business Administration and Marketing, Babcock University, Ilishan-Remo, Ogun State, \\ Nigeria \\ Correspondence: Adegbola Eunice Abimbola, Department of Business Administration and Marketing, Babcock \\ University, Ilishan-Remo, Ogun State, Nigeria. E-mail: eadegbola2@gmail.com
}

Received: March 23, 2020 Accepted: April 24, 2020 Online Published: April 27, 2020

doi:10.5539/ijms.v12n2p78 URL: https://doi.org/10.5539/ijms.v12n2p78

\begin{abstract}
Integrated Marketing Communications (IMCs) is critical to the performance of an organisation. However, many of the previous studies have focussed on manufacturing firms with very few targeted at private universities. Moreover, empirical evidence revealed that private universities have not been able to effectively deploy IMCs to enhance their performance and have been confronted with the challenge of poor customer satisfaction. The study investigated the effect of IMCs on customer satisfaction of selected private universities in South-West Nigeria. The study adopted cross-sectional survey research design. The population of the study comprised 554 employees of the Institutional Marketing Department and ad-hoc staff of the Registry Department of the universities selected for the study. Total enumeration method was used. The instrument used was a validated adapted questionnaire. The Cronbach's alpha reliability coefficients of the constructs ranged from 0.701 to 0.832 . The response rate was $85 \%$. Data were analysed using multiple linear regression. The results revealed that IMCs had positive and significant effect on customer satisfaction (Adj. $\left.\mathrm{R}^{2}=0.834, \mathrm{~F}(5,467)=475.554, \mathrm{p}<0.05\right)$. The relative effects of IMCs on customer satisfaction showed that advertising had a positive and significant effect ( $\beta$ $=0.132, \mathrm{t}=3.038, \mathrm{p}<0.05)$, service promotion had a positive and significant effect $(\beta=0.195, \mathrm{t}=4.502, \mathrm{p}<$ $0.05)$, online marketing had a positive and significant effect $(\beta=0.269, t=5.972, p<0.05)$, public relations also had a positive and significant effect $(\beta=0.377, \mathrm{t}=7.415, \mathrm{p}<0.05)$. The effect of direct marketing was however insignificant though positive $(\beta=0.059, \mathrm{t}=1.130, \mathrm{p}>0.05)$. The study concluded that IMCs affect customer satisfaction. The study recommended that private universities should prioritise their promotional efforts on advertising, service promotion, online marketing and public relations rather than direct marketing in their bid to sustain and improve their customer satisfaction record.
\end{abstract}

Keywords: advertising, customer satisfaction, direct marketing, integrated marketing communications, online marketing, public relations, service promotion

\section{Introduction}

The number of private universities springing up on the African continent has been steadily increasing in recent past with Nigeria recording the fastest growth on the continent (Adetunji \& Ogunleye, 2015). However, the quality of education and the performance of most of the universities particularly in Nigeria has been declining over the years - a situation that may be responsible for the surge in the number of students leaving the country to pursue higher education abroad (Adeniyi, Adediran, \& Opeyemi, 2016; Adetunji, 2015).

According to Higher Education open door (HE, open door, 2017), about 9,494 of Nigerians went abroad to the United States for higher education for the 2014/2015 academic session. In 2015/2016 academic session, a total of 10,674 went to the United States for higher education. The Institute of International Education (IIE) (2017) shows that about 11,710 Nigerian students embarked on study in 2017 in the United States, an upsurge of 9.7\% over 2016.

Integrated marketing communications (IMC) has gained increased recognition over the past few decades. However, the rate at which institutions of higher education (IHEs) have adopted IMC as part of their strategic management approach has not been fully understood (Rosengren \& Dahlén, 2015). The deficiency of a marketing communications focus tends to be the reason for the poor performance of several higher institutions (Yilmaz, 2017). Several researchers such as Adefulu (2016), Joseph, Nsobiari and Benjamin (2014), Muchina and Okello 
(2016), Murianki (2015), Sajuyigbe, Amusat and Oloyede (2013) suggested that it is relevant to investigate how dimensions of integrated marketing communications influence of customer satisfaction as a dimension of performance.

There have been complaints from students in respect to the poor service delivery of some universities (Obadara $\&$ Alaka, 2013). The universities offer services without putting into consideration consumers' (students') needs or preferences. For example, most universities still use the manual registration methods which involves being physically present at the institution rather than online registration (Osarenren-Osaghae \& Irabor, 2012). Further, there are lots of private universities that are largely unknown to the Nigerian public. Students generally do not want to study in schools they cannot boast of, irrespective of its academic potentials, hence a university's inability to secure popularity and reputation might be the path to its doom (Mbon, Etor, \& Osim, 2012).

Considering the foregoing, the aim of this study was to investigate the effect of integrated marketing communications on customer satisfaction of selected private universities in South-west, Nigeria. To achieve this objective, the paper answered the research question-What is the effect of integrated marketing communications on customer satisfaction of selected private universities in South-West, Nigeria? The paper is structured as follows: the introductory section of the paper dealt with the background issues that led to the topic, while section one considered the literature review in line with the concepts, theory, and empirics relating to the study variables. Section two was devoted to methodology adopted for the study with specific emphasis on the population and sample size determination together with data collection. In the third section, the data collected were presented, summarized, analyzed and corresponding findings were discussed, while the fourth and the last section covered the conclusion and recommendations flowing from the findings of the study.

\section{Literature Review}

Lovelock and Wirtz (2011) pointed out that marketing communications mix includes advertising, online marketing, promotions, personal selling, and public relations. Students require information regarding the characteristics of the product or service, its price, how and where to get it in order to make informed enrolment decisions. This suggests that effective communication channels improve the service delivery of the institution as customers (parents, students and potential students) have confidence in their enrolment choice (Kotler, 2011). However, for this holistic approach to be successful, the communications mix must be channelled via the most effective communication platform. Marketing communications mix is an important determinant of awareness creation and interest arousal or trial of product or service which could lead to the acquisition of the product or the service (Kotler \& Keller, 2005). It can add to the performance of the institution by crafting and instilling the product/service or brand in the mind of the consumers (Kotler, 2006). Therefore, IMC is the evidence of combining activities, methods, messages, and goals to ensure consistent communication across organisational borders (Christiana, 2014).

According to Abiodun (2011), advertising is a non-personal paid form of communication about an organisation or its product to a target audience through a mass broadcast medium. Advertising is a promotional tool that enlightens and persuades consumers to accept a product or a brand by reminding, reassuring, and influencing decisions of the consumers. Advertising encompasses all paid messages in the media owned and controlled by people other than the company making the advertisement (Osogbo, 2014).

Promotion means to move forward (Oyebamiji, Kareem, \& Ayeni, 2013). This definition indicates that promotion is a means of communication done with the aim of influencing people to accept ideas, concepts or things. Eagle and Kitchen (2015) see promotion as an essential tool in a constantly changing environment. Promotion is a part of marketing activities, a good promotion can strengthen consumer confidence, because as consumers tend to buy a product based on coupons and other offers. An attractive offer on a regular basis will make consumers relative to a brand that is promoted (Nawaz, 2018).

According to Nadeem, Naveed, Muhammad, and Komal (2013), direct marketing serves as an interactive system of marketing which combines one or more advertising media to create quality relationship between an organization and its customers. Direct marketing provides an avenue for businesses to communicate directly with its customers via multiple media platforms which include print, online adverts, inbound marketing, mobile messaging apps, websites, promotional letters, and so on. Direct marketing often depends on the proposition, offer, communication, choice of channel and the target customer (Donald \& Etokakpan, 2013).

Online marketing involves methods and procedures that when adopted would lead internet users to certain web pages where they can buy products or request for services (French \& Rusell-Bannett, 2015). Consequently, web presence is the sole aim of online marketing. Also, there are other add-ons in online marketing such as banner on a plane which shows a uniform resource locator (URL) (Lammenett, 2014). Online marketing comprises 
promotional activities that are carried out through websites, social networking sites (SNS), emails, mobile phone texts and applications (Kelly, Vandevijvere, Freeman, \& Jenkin, 2015). Public relations are a management function that helps to develop and sustain lines of communications, understanding, acceptance and cooperation to keep updated on public opinion and respond effectively (Rosenberg, 2013). Watson (2012) revealed that public relations is a management function implemented by a wide range of organisations and institutions.

According to Kotler (2009), the term satisfaction is a feeling that extends across the entire consumption horizon. In other words, customer satisfaction is a feeling of pleasure arising from comparing the perceived performance or outcome of a product or service in relation to the expectation of the customer (Aksoy, 2013). Customer satisfaction identifies significant relationship between customer and service provider (Khan \& Fasih, 2014). The interaction between customer and service provider helps businesses to elaborate customized customer needs and expectation at each stage (Nimako, 2010). Customers are the key determinant of the continuous existence and development of a company on the market (Matias, Reis, \& Azevedo, 2015).

There are many studies carried out on integrated marketing communications and performance. However, some researchers have found positive results while others reported negative results (Bassi, 2007). Malik and Ghafoor (2014) investigated the impact of advertisement and consumer perception on customer satisfaction and their results revealed that advertisement and customer satisfaction both had a significant positive relationship. Similarly, Sharma (2012) examined advertising effectiveness by seeking to understanding the value of creativity in advertising by conducting a review study in India and found that creativity in advertisement positively affected customer's choice of purchase and satisfaction. In the same vein, Rinta-Kanto (2012) found that advertising has a significant positive effect on sales revenue and customer satisfaction.

From theoretical perspective, the integrated marketing communications theory argue that application of integrated marketing communication dimensions of promotion, advertising, online marketing, public relations and direct marketing will enhance the various dimensions of institutional performance of which customer satisfaction is prominent.

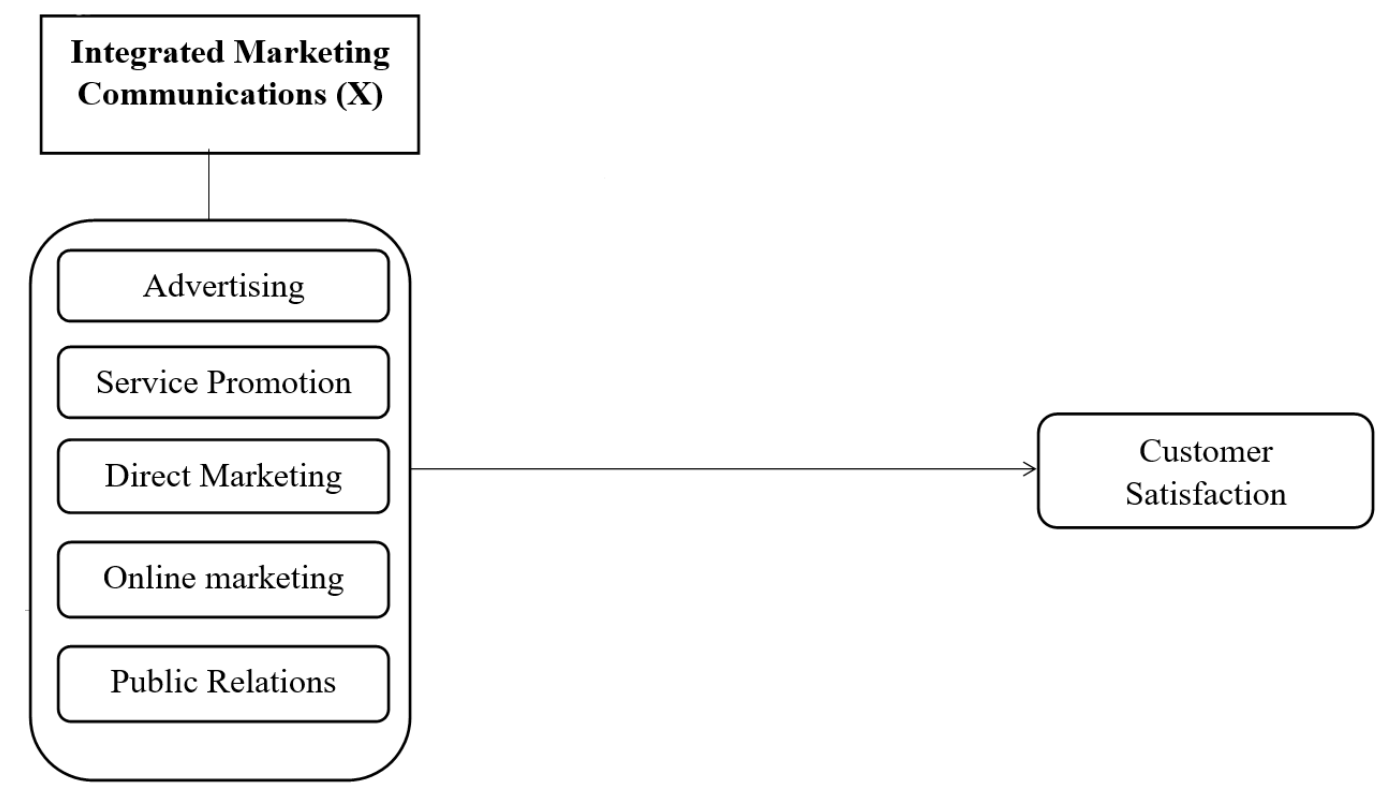

Figure 1. Researcher's conceptual model (2019)

Source: Computed from the literature.

The econometric model.

$$
\mathrm{CS}=\beta_{0}+\beta_{1} \mathrm{AD}+\beta_{2} \mathrm{SP}+\beta_{3} \mathrm{DM}+\beta_{4} \mathrm{OM}+\beta_{5} \mathrm{PR}+\mathrm{e}_{\mathrm{i}}
$$

\section{Methodology}

Cross-sectional survey research design was adopted for this study considering that primary data was required for the study and since this research design affords the researcher the opportunity of getting firsthand and current 
information that is reliable and authentic for the intended purpose. The population for this study were 554 employees of twenty (20) selected private universities who were involved in the enrolment process for the 2019/2020 academic session. Total enumeration of the five hundred and fifty-four (554) staff that were involved in the 2019/2020 academic session enrolment were considered.

Data were collected using a validated structured adapted questionnaire. The Cronbach's alpha coefficients of the variables ranged from 0.701 to 0.832 . A total of 473 copies of questionnaire were properly filled and returned. This represented an overall response rate of $85 \%$.

\section{Data Analysis}

Inferential statistics was used to analysed data collected. Inferential statistics was used to measure the aspects of the effect between integrated marketing communications and customer satisfaction. Multiple linear regression analysis was applied to test the hypothesis since this study sought to establish the effect of several integrated marketing communications dimensions on customer satisfaction. This method was suitable because it found the target variables by finding a best suitable fit line between the independent sub-variables and the dependent variable.

Table 1. Summary of multiple regression analysis for effects of integrated marketing communications dimensions on customer satisfaction of selected private universities in South-West, Nigeria

\begin{tabular}{lllllllll}
\hline $\mathbf{N}$ & Model & $\boldsymbol{B}$ & Sig. & $\mathbf{T}$ & ANOVA (Sig.) & $\mathbf{R}^{2}$ & Adjusted $\mathbf{R}^{2}$ & $\mathbf{F}(\mathbf{d f})$ \\
\hline 473 & (Constant) & -0.961 & 0.062 & -1.868 & $0.000^{\mathrm{b}}$ & 0.836 & 0.834 & $475.554(5,467)$ \\
& Advertising & 0.132 & 0.003 & 3.038 & & & & \\
& Service promotion & 0.195 & 0.000 & 4.502 & & & \\
& Direct marketing & 0.059 & 0.259 & 1.130 & & & \\
& Online marketing & 0.269 & 0.000 & 5.972 & & & \\
& Public relations & 0.377 & 0.000 & 7.415 & & & \\
& Predictors: (Constant), Advertising, Service promotion, Direct marketing, Online marketing, Public relations \\
&
\end{tabular}

Source: Field Survey, 2019

$$
\mathrm{CS}=-0.961+0.132 \mathrm{AD}+0.195 \mathrm{SP}+0.269 \mathrm{OM}+0.377 \mathrm{PR}
$$

Table 1 reveals the result of the multiple regression analysis for the effect of integrated marketing communications dimensions (advertising, service promotion, direct marketing, online marketing and public relations) on customer satisfaction of selected private universities in South-West Nigeria. The above model showed that out of all the dimensions of integrated marketing communications, advertising, service promotion, online marketing and public relations have positive and significant effect on customer satisfaction of selected private universities in South-West, Nigeria. The results indicated that advertising, service promotion, online marketing and public relations all have individual positive and significant effect on customer satisfaction while direct marketing has a positive and insignificant effect on customer satisfaction of selected private universities in South-West, Nigeria. The result further revealed that integrated marketing communications dimensions explained $83.4 \%$ of the changes in customer satisfaction of selected private universities in South-West, Nigeria.

The model revealed that when advertising, service promotion, online marketing and public relations are improved by one unit, customer satisfaction will also increase by $0.132,0.195,0.269$ and 0.377 respectively.

\section{Discussion}

The result of the effect of integrated marketing communications dimensions on customer satisfaction of selected private universities in South-West, Nigeria was determined in this study. The results revealed that integrated marketing communications has a positive and significant effect on customer satisfaction of selected private universities in South-West Nigeria. This implies that advertising, service promotion, online marketing and public relations should be the focus of private universities in South-West, Nigeria if they are to satisfy their customers both students and stakeholders.

The finding of this is in alignment with that of Khan and Fasih (2014) who reported that every producer or service provider is engaged in removing false claims and exaggerations which is deceptions; while, promoting and campaigning for the products and services. Similarly, Sharma (2012) investigated advertising effectiveness in India and discovered that creativity in advertisement positively affected customer's choice of purchase and 
satisfaction; while considering the interaction between integrated marketing communications dimensions and consumer behaviour. In the same vein, Rinta-Kanto (2012) reported that advertising has a significant positive effect on sales revenue and customer satisfaction.

\section{Conclusion and Recommendation}

The general purpose of this study was to examine effect of integrated marketing communications dimensions on customer satisfaction of selected private universities in South-WestNigeria. From the data collected, the respondents reported that the result of the hypothesis showed that advertising, service promotion, online marketing and public relations have positive and significant effect on customer satisfaction. Limitationof this study was incomplete responses by some of the respondents. However, this limitation was mitigated as the incomplete responses were invalidated so as not to affect the results of this study. Based on the findings of this study, the study recommended that universities, especially private universities should constantly use advertising, service promotion, online marketing and public relations should be the focus of private universities in South-West, Nigeria if they are to satisfy their customers both students and stakeholders.

\section{References}

Abiodun, A. O. (2011). The Impact of Advertising on Sales Volume of a product. A Case Study of Starcomms Plc, Nigeria. Valkeakoski Degree Programme in International Business Global Market, HAMK University.

Adefulu, A. (2016). Examination of the relevance of personal selling in marketing activities: A descriptive method. Journal of Accounting and Management, 6(2), 103-116.

Adetunji, A. T. (2015a). Understanding government policies in university education: A study of Nigeria university management. Journal of Education, 3(3), 1-17.

Adetunji, A. T. (2015b). Implementing government policies in university education: Challenges faced by Nigerian universities' principal officers. Net Journal of Social Sciences, 3(1), 9-16. https://doi.org/10.21744/irjmis.v3i3.92

Adetunji, A. T., \& Ogunleye, K. A. (2015). Effect of government policies on university administrators: A Nigeria review. Ge-International Journal of Management Research, 3(5), 56-69.

Adetunji, A., Adeniran, O., \& Opeyemi, O. (2016). Contemporary problems in Nigeria private university that affects quality. International Journal of Multidisciplinary Research Review, 3, 1874-1879.

Aksoy, L. (2013). How do you measure what you can't define? The current state of loyalty measurement and management. Journal of Service Management, 24, 356-381. https://doi.org/10.1108/JOSM-01-2013-0018

Bassi, M. (2007). Academic self-efficacy beliefs and quality of experience in learning. Journal of Youth and Adolescence, 36, 301-312. https://doi.org/10.1007/s10964-006-9069-y

Christiana, S. A.-J. (2014). An empirical investigation of the effectiveness of sales promotion in maltina and maltaguinness sales promotion strategies. Journal of Mass Communication and Journalism, 4(7), 1-5.

Donald, I. O., \& Etokakpan, M. U. (2013). The impact of sales promotion on sales: A case of selected telecommunication firms in Nigeria. The IUP Journal of Marketing Management, 12(2), 23-43.

Eagle, L., \& Kitchen, P. J. (2015). IMC, brand communications, and corporate cultures: Client/advertising agency coordination and cohesion. European Journal of Marketing, 34(5/6), 667-686. https://doi.org/10.1108/03090560010321983

French, J., \& Rusell-Bannett, R. (2015). Effect of online marketing strategies on performance of telecommunication companies: A case of Safaricom Limited. International Academic Journal of Information Systems and Technology, 2(1), 49-60.

Joseph, A. A., Nsobiari, F. A., \& Benjamin, B. E. (2014). The impact of personal selling on the productivity of selected banks in Calabar Metropolis. International Journal of Development and Sustainability, 3(8), 1697-1708.

Kelly, B., Vandevijvere, S., Freeman, B., \& Jenkin, G. (2015). New Media but Same Old Tricks: Food Marketing to Children in the Digital Age. Current Obesity Reports, 4(1), 37-45. https://doi.org/10.1007/s13679-014-0128-5

Khan, M. M., \& Fasih, M. (2014). Impact of service quality on customer satisfaction and customer loyalty: Evidence from banking sector. Pakistan Journal of Commerce and Social Sciences, 8(2), 331-354.

Kotler, P. (2006). Marketing Management. New Jersey: Person Education. 
Kotler, P. (2009). Marketing Management (13th ed.). New Jersey: Prentice-Hall, Englewood Cliffs.

Kotler, P. (2011). Reinventing marketing to manage the environmental imperative. Journal of Marketing, 75(4), 132-135. https://doi.org/10.1509/jmkg.75.4.132

Kotler, P., \& Keller, K. (2005). Marketing Management (12th ed.). New Jersey: Pearson/Prentice Hall, Upper Saddle River.

Lammenett, E. (2014). Praxiswissen Online-Marketing. Switzerland: Springer Gabler. https://doi.org/10.1007/978-3-658-03313-2

Lovelock, C., \& Wirtz, J. (2011). Services marketing: People, technology, strategy (7th ed.). UK: Prentice Hall.

Malik, M. E., \& Ghafoor, M. M. (2014). Importance of brand awareness and brand loyalty in assessing purchase intentions of consumer. International Journal of Business and Social Science, 4(5), 167-171.

Matias, J. C. O., Reis, M., \& Azevedo, S. G. (2015). Framework to analyse the influence of quality on customer satisfaction in the Mobile Telecommunication sector. Quality Access Success, 16, 85-92.

Mbon, U. F., Etor, C. R., \& Osim, R. O. (2012). Enhancing quality assurance through lecturers' job performance in private and public tertiary institutions in south eastern Nigeria. Journal of Emerging Trends in Educational Research and Policy Studies, 3(6), 837-841.

Muchina, C. M., \& Okello, B. (2016). Influence of personal selling on brand performance of retail shoe companies in Nairobi Central business district. International Journal of Academic Research in Business and Social Sciences, 6(5), 1-14. https://doi.org/10.6007/IJARBSS/v6-i5/2113

Murianki, M. (2015). Effects of personal selling on sales: A case of women groups in Imenti North District, Meru County. Kenya. International Journal of Academic Research in Business and Social Sciences, 5(1), 13-27. https://doi.org/10.6007/IJARBSS/v5-i1/1398

Nadeem, I., Naveed, A., Muhammad, E., \& Komal, C. (2013). The role of sales promotion on sales volume in the context of fast-moving consuming goods (FMCG) industry in Dera Ghazi Khan. International Journal of Accounting Research, 1(4), 234-254.

Nawaz, A. (2018). Impact of products, promotion and after sale services on satisfaction of PTCL's (Pakistan Telecommunication Company Ltd.) Customers. Review of Public Administration and Management, 6(1), 1-14. https://doi.org/10.4172/2315-7844.1000244

Nimako, S. G. (2010). Overall customer satisfaction in Ghana's Mobile. ATDF Journal, 7, 35-46.

Nowak, G. J., \& Phelps, J. (1994). Conceptualizing the integrated marketing communications' phenomenon: an examination of its impact on advertising practices and its implications for advertising research. Journal of Current Issues and Research in Advertising, 16(1), 49-66. https://doi.org/10.1080/10641734.1994.10505012

Obadara, O. E., \& Alaka, A. A. (2013). Accreditation and quality assurance in Nigerian universities. Journal of Education and Practice, 4(8), 34-41.

Osarenren-Osaghae, R., \& Irabor, Q. (2012). Availability and adequacy of human and material resources for the teaching and learning of skill-based courses in Nigeria Public Universities. Journal of Sociology and Social Anthropology, 3(1), 15-27. https://doi.org/10.31901/24566764.2012/03.01.03

Osogbo, R. (2014). Effects of advertising on organisational profitability. Journal of Management and Social Sciences, 3(1), 67-72.

Oyebamiji, F. F., Kareem, T. S., \& Ayeni, G. O. (2013). Impact of job satisfaction dimensions on job performance in a small and medium enterprise in Ibadan, South Western, Nigeria. Interdisciplinary Journal of Contemporary Research in Business, 4(11), 509-521.

Rinta-Kanto, S. (2012). The effect of traditional advertising campaigns on online affiliate channel performance - A case of a leading international hotel booking website. Aalto university school of economics.

Rosenberg, M. (2013). This is PR: The realities of public relations (11th ed.). Wadsworth: Cengage Learning.

Rosengren, S., \& Dahlén, M. (2015). Exploring advertising equity: how a brand's past advertising may affect consumer willingness to approach its future Ads. Journal of Advertising, 44(1), 1-13. https://doi.org/10.1080/00913367.2014.961666 
Sajuyigbe, A., Amusat, W., \& Oloyede, O. (2013). Impact of advertising on organisational sales turnover: Nigerian Breweries Plc Experience. European Journal of Business and Management, 5(4), 22-26.

Sharma, P. (2012). Advertising effectiveness: Understanding the value of creativity in advertising, a review study in India. Online Journal of Communication and Media Technologies, 2(3), 1-10. https://doi.org/10.29333/ojcmt/2386

Watson, T. (2012). The evolution of public relations measurement and evaluation. Public Relations Reviewn, 14, 1-18. https://doi.org/10.1016/j.pubrev.2011.12.018

\section{Copyrights}

Copyright for this article is retained by the author, with first publication rights granted to the journal.

This is an open-access article distributed under the terms and conditions of the Creative Commons Attribution license (http://creativecommons.org/licenses/by/4.0/). 